\title{
Secondary Macronutrients Up-Take, Root Development, and Chlorophyll Content of Local Rice Varieties Grown under System of Rice Intensification (SRI) vs. Conventional Methods
}

\author{
Bambang Heri Isnawan ${ }^{\#, *}$, Supriyono ${ }^{+}$, Supriyadi $^{+}$, Samanhudi $^{+}$ \\ ${ }^{\#}$ Doctoral Program of Agricultural Science, Graduate School, Universitas Sebelas Maret, Surakarta, Indonesia 57126 \\ E-mail:bambanghi@umy.ac.id \\ ${ }^{+}$Department of Agrotechnology, Faculty of Agriculture, Universitas Sebelas Maret, Surakarta, Indonesia 57126 \\ E-mail: samanhudi@staff.uns.ac.id
}

*Department of Agrotechnology, Faculty of Agriculture Universitas Muhammadiyah Yogyakarta, Yogyakarta, Indonesia 55183

\begin{abstract}
A System of Rice Intensification (SRI) create optimal conditions with transplanting widely spaced young single seedlings, organic fertilizer amendment, and water management. In Indonesia the water for irrigating rice is limited, especially in the dry season. An Intermittent irrigation method of rice cultivation aims to reduce water requirements. In Indonesia local rice varieties have the potential to produce high-yielding rice with the intermittent irrigation method to meet food needs. The study aims to determine the suitability of SRI and conventional irrigation techniques on local rice varieties. The research conducted the field experimental with $4 \times 2$ factorial design, arranged in a Randomized Completely Block Design with three replications. The first factor was rice varieties, which consisted of 4 varieties, i.e., Rojolele, Cianjur, Mentikwangi and Ciherang. The second factor was the method of irrigation consisting of two kinds, i.e., intermittent irrigation and continuous flooding. Analysis of variance and Duncan's Multiple Range Test at $\alpha=5 \%$ was used. The results showed that rice variety and irrigation were significantly interacts to the secondary macronutrient absorption and root development. Rojolele with SRI irrigation has higher secondary macronutrient absorption than the Cianjur and Mentikwangi. Calcium nutrient absorption of Rojolele and Ciherang with SRI irrigation was higher than other varieties, whereas Magnesium nutrient absorption of Rojolele with SRI irrigation was higher than Ciherang, Cianjur, and Mentikwangi. Rojolele with SRI irrigation had higher Sulfur nutrient absorption than Cianjur and Mentikwangi. In Rojolele and Ciherang, intermittent irrigation SRI produced longer roots at harvest and more wide root surface area than conventional irrigation, but on Mentikwangi, conventional irrigation produced longer roots and more wide root surface area than intermittent SRI irrigation. The chlorophyll b content of the Cianjur and Mentikwangi were greater than Rojolele. The yield of Cianjur was higher than Ciherang's variety.
\end{abstract}

Keywords — intermittent; aromatic rice variety; SRI; continuous flooding.

\section{INTRODUCTION}

Rice (Oryza sativa L.) is an important crop and is a strategic commodity. Rice plays an important role not only as a staple food source but as the main source of income for most rural communities. Lack of production may influence various aspects of life, including social, economic, even political aspects [1]. The relatively large increases in rice production in 2017 were found in the provinces of Central Java, East Java, South Sumatra, and Aceh [2]. One of the most important constraints on System of Rice Intensification (SRI) adoption is water availability, being able to manage irrigation systems sufficiently to provide reduced but reliable amounts of water on an intermittent basis. Where fields are low-lying and continuously submerged or mostly saturated, SRI methods will not produce their best results. Water control is relative, not an absolute requirement [3]. The use of water for rice cultivation needs to be saved, especially during the dry season or when water availability is limited, so the SRI method of rice cultivation needs to be 
applied with intermittent irrigation between inundation and drying.

Water in the future will be increasingly scarce, so there should be alternative ways of irrigation, intermittent irrigation. Intermittent irrigation is the regulation of land conditions in dry and submerged conditions in turn to 1) Save irrigation water so that the irrigated area becomes wider; 2) Give the root a chance to get air so that it can develop deeper; 3) Prevent iron poisoning; 4) Prevent the accumulation of organic acids and $\mathrm{H}_{2} \mathrm{~S}$ gas which inhibits root development [4], so that there is a development on the intermittent irrigation.

SRI is an agroecological approach to rice cultivation that seeks to create optimal conditions for healthy plant growth by minimizing inter-plant competition, transplanting widely spaced young single seedlings, and optimizing favorable soil conditions with organic amendments, increased soil aeration by weeding, and controlled water management [5]. Water management controls with flooding, and intermittent irrigation SRI method of rice cultivation is a breakthrough in rice cultivation by changing the management of plants, soil, water, and nutrients. This technique can offer water-saving technology, saving seeds, and saving fertilizer. Compared to the conventional pattern of rice cultivation, the SRI method of rice cultivation can save seeds by up to one third.

Many researchers have conducted various studies on SRI method rice including the use of SRI organic fertilizers and the combination of organic and inorganic fertilizers in the semiorganic farming system [6] SRI method rice using banana weevil Local Micro Organism/LMO [7], LMO golden snails, and rabbit urine LMO [8], comparison of SRI and conventional methods [9], SRI with different genotypes [10], flooding and intermittent irrigation in 3 trials [11]; [12], conventional irrigation, inundation of 35 Day After Tansplanting (DAT), and flooding of 45 DAT [13]. Drying intervals of 2 days, 6 and 8 days and flooding intervals of 2 to 3 days [14], organic SRI rice cultivation systems [15], width of beds with flooding systems in the moat [16], the yield test of 5 rice varieties [17], treatment of seed age, number of seeds per hole, and type of irrigation [18], effect year, practice and line spacing [19], affect the populations and diversity of soil microorganisms [5]. These studies have not yet seen any research on the different aspects of local rice varieties in Indonesia, so it is necessary to study intermittent irrigation on superior local varieties of rice.

The benefits of Calcium are activating the formation of root and seed feathers, strengthening the stem, helping the success of pollination, helping the cell breakdown, and helping the activity of several enzymes [20]

Magnesium ( $\mathrm{Mg}$ ) is absorbed in the form of $\mathrm{Mg}^{2+}$ ions and is the only constituent mineral of chlorophyll and plays an important role in activating several enzymes in plant system [20]. Each chlorophyll molecule contains one magnesium atom. The absence of magnesium makes plants unable to carry out photosynthesis. Magnesium can be transplanted from the old to the young when deficiencies begin

Sulfur is a constituent of essential amino acids (cystine, cysteine, methionin) which are involved in the formation of chlorophyll, and are needed in protein synthesis and plant structure. Sulfur is also a constituent of coenzyme A and the biotin and thiamine hormones needed in carbohydrate metabolism [21] Plants absorb sulfur through the roots in the form of $\mathrm{SO}_{4}{ }^{-}$ions and can be absorbed through leaves in the form of $\mathrm{SO}_{2}^{-}$ions.

This research aimed to study the interaction of superior local rice varieties and SRI intermittent irrigation on secondary macronutrient up-take, to root growth, and chlorophyll content; the effect of SRI intermittent irrigation to the secondary macronutrient up-take, to root growth, and chlorophyll content; and the response of superior local rice varieties on secondary macronutrient absorption, to root growth and chlorophyll content.

\section{MATERIAL AND METHODS}

Research materials included rice seeds of Mentikwangi, Cianjur, Rojolele, and Ciherang varieties, manure, Urea, SP36 , and $\mathrm{KCl}$. The tools used were ruler, $0.01 \mathrm{~g}$ electrical scales, leaf area meter, spectrophotometer UV, and a grain moisture meter. The study was conducted by field experimental method with a 4x2 strip plot design with 3 blocks arranged in a Completely Randomized Block Design. The factor I of the irrigation system, i.e., intermittent irrigation SRI and conventional irrigation. Factors II of rice varieties, i.e., Mentikwangi, Cianjur, Rojolele, and Ciherang.

The nursery was done 12 days before planting and tillage one week before planting. The planting process was at the age of 12 days with a spacing of $25 \mathrm{~cm} \times 25 \mathrm{~cm}, 1-2$ seeds per hole. Plot size measuring $2.25 \mathrm{~m} \times 3.25 \mathrm{~m}^{2}$. Planting was under the conditions of messy water. Replanting was done one week after planting with seeds of the same age. Intermittent irrigation SRI was carried out by flooding of about $2-5 \mathrm{~cm}$, at the beginning of planting up to 10 day after transplanting (DAT), then dried 5-6 days until cracks, flooded again. Watering continues until it enters the flowering phase. Since the phase of flower exiting up to 10 days before harvest, the land was flooded as high as about 5 $\mathrm{cm}$, then 10 days before harvest when maturing until the harvest was dried. Conventional irrigation (A2), carried flooding approximately $5-10 \mathrm{~cm}$ continuously at all stages of growth. Urea fertilization was performed 3 times, at the time of planting, $5 \mathrm{WAT}$, and just before flower primordia at a dose of $200 \mathrm{~kg} / \mathrm{ha}$. Giving SP-36 fertilizer was when planting at a dose of $200 \mathrm{~kg} / \mathrm{ha}$ SP-36. The application of $\mathrm{KCl}$ fertilizer was carried out two times at 5 week after transplanting (WAT) and before the flower primordia with a dose of $100 \mathrm{~kg} / \mathrm{ha} \mathrm{KCl}$.

Observations included analysis of plant tissue, root development, and chlorophyll content. Plant tissue analysis included total $\mathrm{Ca}, \mathrm{Mg}$, and $\mathrm{S}$ content, total $\mathrm{Ca}, \mathrm{Mg}$, and $\mathrm{S}$ absorption. Root development includes total root length and total surface area. Chlorophyll analysis included chlorophyll $\mathrm{a}$, chlorophyll b, and total chlorophyll. Data were analyzed using analysis of variance with a level of $\alpha=5 \%$ and followed by Duncan's Multiple Range Test at $\alpha=5 \%$ with SAS for University Edition. Correlation analysis aimed to determine the closeness of the relationship between the variables, while to determine the pattern of relationships used regression analysis with SPSS software. 


\section{RESULTS AND DISCUSSION}

A. Calcium (Ca), Magnesium (Mg) and Sulfur (S) content 1) Ca Content

The results of the analysis of plant $\mathrm{Ca}$ content in Figure

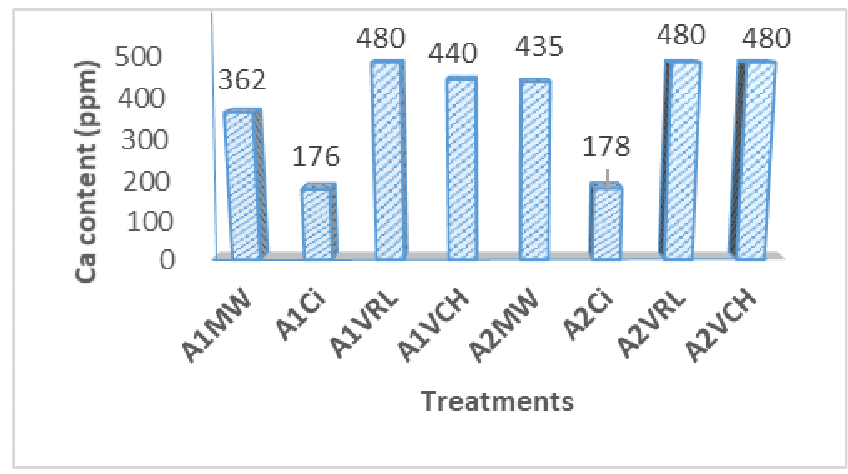

Fig. 1 Calcium Content of Rice Plants
MW = Mentikwangi
$\mathrm{RL}=$ Rojolele Genjah
$\mathrm{Ci}=$ Cianjur
$\mathrm{A} 1=\mathrm{SRI}$
$\mathrm{CH}=$ Ciherang
$\mathrm{A} 2=$ non SRI

Rojolele, Ciherang, and Mentikwangi varieties with conventional and intermittent irrigation had a relatively higher total $\mathrm{Ca}$ content of plants than Cianjur varieties. Conventional irrigation of Mentikwangi, Cianjur and Ciherang varieties had a relatively higher total Ca content of plants than intermittent irrigation (Figure 1). There were differences in the response of rice varieties to $\mathrm{Ca}$ content.

\section{2) $\mathrm{Mg}$ Content}

The results of $\mathrm{Mg}$ content analysis of total plant tissue in Figure 2.

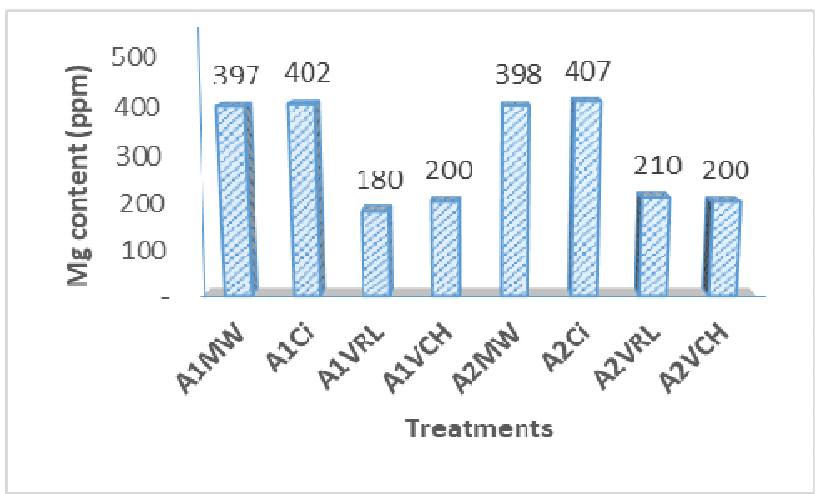

Fig. 2 Magnesium Content of Rice Plants

$$
\begin{array}{ll}
\text { MW }=\text { Mentikwangi } & \mathrm{Ci}=\text { Cianjur } \\
\text { RL }=\text { Rojolele Genjah } & \mathrm{CH}=\text { Ciherang } \\
\mathrm{A} 1=\text { SRI } & \mathrm{A} 2=\text { non SRI }
\end{array}
$$

Cianjur and Mentikwangi varieties with conventional irrigation and intermittent rice had a higher total $\mathrm{Mg}$ content than the Rojolele and Ciherang varieties (Figure 2). Conventional irrigation of Mentikwangi, Cianjur, and Rojolele varieties had a higher total $\mathrm{Mg}$ content of plants than intermittent irrigation. This showed that local rice varieties had relatively higher total $\mathrm{Mg}$ content than superior variety. This showed that there were local rice varieties with conventional irrigation were more responsive to the total $\mathrm{Mg}$ content of plant tissue.

\section{3) S Content}

The results of the S content total analysis in Figure 3.

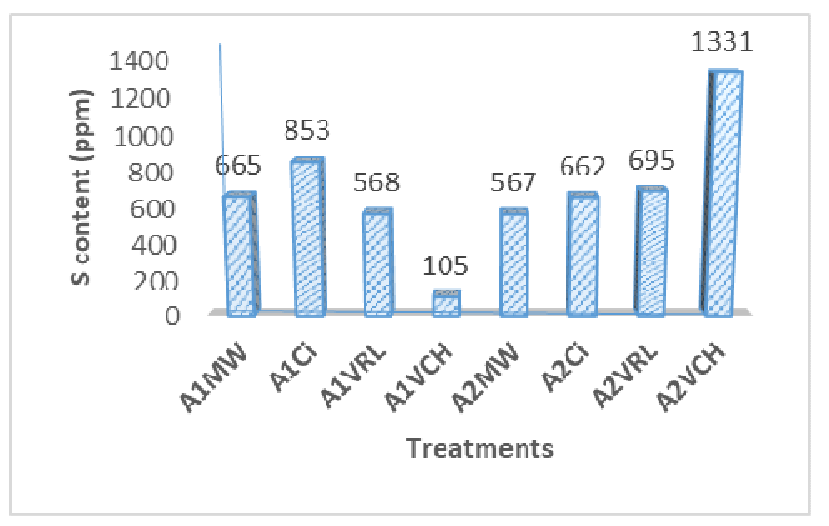

Fig. 3 Sulfur Content of Rice Plants

$$
\begin{aligned}
& \text { MW }=\text { Mentikwangi } \\
& \text { RL }=\text { Rojolele Genjah } \\
& \text { A1 }=\text { SRI }
\end{aligned}
$$$$
\begin{aligned}
\mathrm{Ci} & =\text { Cianjur } \\
\mathrm{CH} & =\text { Ciherang } \\
\mathrm{A} 2 & =\text { non SRI }
\end{aligned}
$$

Ciherang varieties with conventional irrigation and Cianjur varieties with intermittent irrigation had a higher total Plant $S$ content than other varieties (Figure 3). In intermittent irrigation, Cianjur and Mentikwangi varieties had a higher total plant $\mathrm{S}$ content than other varieties. In SRI irrigation, Ciherang and Rojolele varieties had higher total plant $\mathrm{S}$ content than conventional irrigation. Ciherang variety with conventional irrigation were most responsive to the total $\mathrm{S}$ content of plant tissue.

\section{B. $\mathrm{Ca}, \mathrm{Mg}$ and $\mathrm{S}$ absorption}

\section{1) Ca absorption}

The results of the analysis of $\mathrm{Ca}$ absorption total of rice plant in Table 1.

TABLE I

Average Of The Total Ca Absorption (Mg/G) Of Rice Plant Tissue AT 14 WEEKS

\begin{tabular}{|l|l|l|c|}
\hline Treatments & Conventional & SRI & Average \\
\hline Rojolele & $0.072 \pm 0.005 \mathrm{~b}$ & $0.241 \pm 0.052 \mathrm{a}$ & 0.157 \\
\hline Cianjur & $0.068 \pm 0.024 \mathrm{bc}$ & $0.021 \pm 0.004 \mathrm{~d}$ & 0.045 \\
\hline Mentikwangi & $0.023 \pm 0.002 \mathrm{~d}$ & $0.027 \pm 0.009 \mathrm{~cd}$ & 0.025 \\
\hline Ciherang & $0.078 \pm 0.007 \mathrm{~b}$ & $0.221 \pm 0.048 \mathrm{a}$ & 0.150 \\
\hline Average & 0.241 & 0.510 & $(+)$ \\
\hline
\end{tabular}
The average number followed by the same letter in a row and column shows
not significantly different in DMRT at $\alpha=5 \%$.
$(+)=$ There is a significant interaction between varieties and irrigation.

Rice variety and irrigation are significant interactions with the $\mathrm{Ca}$ absorption. On Rojolele and Ciherang varieties, Calcium absorption with SRI irrigation was higher than conventional. On Cianjur variety, Calcium nutrient absorption with intermittent irrigation was lower than conventional, whereas, on Mentikwangi variety, Calcium nutrient absorption with intermittent irrigation is not 
significantly different from conventional ones. Rice of Cianjur variety with conventional irrigation can absorb nutrient $\mathrm{Ca}$ significantly higher than SRI irrigation. This Cianjur variety with conventional irrigation is more responsive in absorbing $\mathrm{Ca}$ than intermittent irrigation. Intermittent and conventional irrigation methods provide total $\mathrm{Ca}$ absorption of rice tissue in Mentikwangi varieties not significantly different (Table 1).

Under SRI intermittent irrigation, the total $\mathrm{Ca}$ absorption of Ciherang rice plant tissue is the highest, because Ciherang is a superior variety that was more responsive to Ca nutrient absorption than most local rice varieties. Rojolele rice, although it was a local variety, has the highest Ca nutrient absorption than the local varieties of Cianjur and Mentikwangi, not significantly with Ciherang. This result shows that Rojolele variety had the most responsive to $\mathrm{Ca}$ absorption. In SRI irrigation, during the dry period, the activity of soil organic matter can be higher so that the process of mineralization of $\mathrm{Ca}$ is higher, and its nutrients absorption by plants are greater.

\section{2) Mg absorption}

Rice variety and irrigation are significant interactions with the $\mathrm{Mg}$ absorption. On Rojolele and Ciherang, varieties with intermittent irrigation had significantly higher $\mathrm{Mg}$ absorption of plants than conventional irrigation (Table 2). Rice varieties of Cianjur and Mentikwangi had Mg absorption of plants not significantly different between types of irrigation. It showed that Rojolele's local rice has the same response as Ciherang variety rice.

In intermittent irrigation, Rojolele Variety had significantly higher $\mathrm{Mg}$ absorption than Ciherang, and both varieties had significantly higher $\mathrm{Mg}$ absorption than Cianjur and Mentikwangi varieties. In conventional irrigation, rice Ciherang and Rojolele varieties had $\mathrm{Mg}$ absorption not significantly different, and both varieties had significantly higher $\mathrm{Mg}$ absorption than Cianjur and Mentikwangi varieties.

TABLE II

Average Of The Total Mg Absorption (Mg/G) OF Rice Plant Tissue AT 10 WEEKS

\begin{tabular}{|l|c|c|c|}
\hline Treatments & Conventional & SRI & Average \\
\hline Rojolele & $0.031 \pm 0.002 \mathrm{c}$ & $0.074 \pm 0.015 \mathrm{a}$ & 0.053 \\
\hline Cianjur & $0.014 \pm 0.004 \mathrm{~d}$ & $0.013 \pm 0.004 \mathrm{~d}$ & 0.014 \\
\hline Mentikwangi & $0.009 \pm 0.001 \mathrm{~d}$ & $0.009 \pm 0.001 \mathrm{~d}$ & 0.009 \\
\hline Ciherang & $0.032 \pm 0.003 \mathrm{c}$ & $0.048 \pm 0.009 \mathrm{~b}$ & 0.040 \\
\hline Average & 0.022 & 0.036 & $(+)$ \\
\hline
\end{tabular}

The average number followed by the same letter in a row and column shows not significantly different in DMRT at $\alpha=5 \%$.

$(+)=$ There is a significant interaction between varieties and irrigation.

This result showed that local varieties of Rojolele rice with intermittent irrigation had higher $\mathrm{Mg}$ absorption than varieties of Cianjur and Mentikwangi. It means that genetic factors had more influence on rice varieties of local varieties with more responsive by intermittent irrigation to $\mathrm{Mg}$ absorption.

In SRI irrigation, the total $\mathrm{Mg}$ absorption of Rojolele rice plant tissue was the highest in the absorption of other varieties. Although Rojolele is a local variety, it is most responsive to $\mathrm{Mg}$ nutrient absorption than most local rice varieties, even more responsive in $\mathrm{Mg}$ absorption than Ciherang rice, which was a superior variety. This result showed that Rojolele Rice had the most responsive to $\mathrm{Mg}$ absorption. In SRI irrigation, during the dry period, it enabled higher soil organic material activity so that the $\mathrm{Mg}$ mineralization process is higher and the $\mathrm{Mg}$ nutrients absorbed are greater.

\section{3) S Absorption.}

Sulfur is a constituent of essential amino acids (cystine, cysteine, methionine) which are involved in the formation of chlorophyll, and are necessary for protein synthesis and plant structure. Sulfur is also a constituent of coenzyme A and the biotin and thiamine hormones needed in carbohydrate metabolism [22]. Plants absorb sulfur through the roots in the form of $\mathrm{SO}^{4-}$ ions and leaves in the form of $\mathrm{SO}^{2-}$ ions. The results of the analysis of the plant total $\mathrm{S}$ were presented in Table 3 .

TABLE III

Average Of The Totals Absorption (MG/G) Of Rice Plant Tissue At 14 WEEKS

\begin{tabular}{|l|l|l|c|}
\hline Treatments & Conventional & SRI & Average \\
\hline Rojolele & $0.054 \pm 0.015 \mathrm{~cd}$ & $0.285 \pm 0.062 \mathrm{~b}$ & 0.170 \\
\hline Cianjur & $0.103 \pm 0.037 \mathrm{c}$ & $0.102 \pm 0.021 \mathrm{c}$ & 0.103 \\
\hline Mentikwangi & $0.073 \pm 0.006 \mathrm{~cd}$ & $0.050 \pm 0.017 \mathrm{~cd}$ & 0.062 \\
\hline Ciherang & $0.819 \pm 0.090 \mathrm{a}$ & $0.005 \pm 0.001 \mathrm{~d}$ & 0.412 \\
\hline Average & 0.262 & 0.110 & $(+)$ \\
\hline
\end{tabular}

The average number followed by the same letter in a row and column shows not significantly different in DMRT at $\alpha=5 \%$.

$(+)=$ There is a significant interaction between varieties and irrigation.

Rice variety and irrigation are significant interactions with the $\mathrm{S}$ absorption. Ciherang variety with conventional irrigation had significantly higher plant $S$ absorption than intermittent Rojolele. Both varieties and types of irrigation had significantly higher $\mathrm{S}$ absorption than other varieties. Ciherang variety with conventional irrigation was the most responsive to total $S$ absorption of plant tissue. In intermittent irrigation, Rojolele Varietal rice had significantly higher $\mathrm{S}$ absorption than other varieties.

In conventional irrigation, Rice varieties of Cianjur, Rojolele, and Mentikwangi had $\mathrm{S}$ absorption not significantly different, and these three varieties had lower $\mathrm{S}$ absorption than Ciherang variety significantly (Table 3 ).

In conventional irrigation, the total $S$ absorption of Ciherang rice plant tissue was highest, because Ciherang is a superior variety that is more responsive to $S$ nutrient absorption than other varieties. In SRI irrigation, although Rojolele rice is a local variety, it had higher $\mathrm{S}$ nutrient absorption than the local varieties of Cianjur and Mentikwangi. It showed that Rojolele Rice had the most responsive to $\mathrm{S}$ absorption than other local rice varieties because the Rojolele Genjah rice was the result of improving the nature of Rojolele Gepyok, which has a longer life. Rojolele Genjah had a higher response than Rojolele Gepyok. In conventional irrigation, during periods of inundation allows higher accumulation of $S$ and nutrients absorption so that the highest $\mathrm{S}$ absorption was Ciherang rice. 


\section{B. Root development}

\section{1) Root length Total.}

The total root length total was measured at $13^{\text {th }}$ weeks using a Leaf Area Meter with a Licor Type with the Regression Method. The results of the analysis of variance and Duncan's Multiple Range test were presented in Table 4, showed that there was significant interaction between varieties and types of irrigation.

In intermittent irrigation, the roots length total of Rojolele, Cianjur, Mentikwangi, and Ciherang varieties were not significantly different. In conventional irrigation, the roots length total of local rice of the Cianjur variety was significantly longer than the Rojolele and Ciherang varieties (Table 4).

In SRI intermittent irrigation, the total root length between rice varieties was not significantly different because, with SRI intermittent irrigation, there was a dry period that allows total roots to grow longer in all rice varieties. In conventional irrigation, the Cianjur variety had a longer total root than other varieties, indicating that this variety was more resistant to inundation than other varieties.

TABLE IV

Average Of The Root Length Total Of Rice Plant Tissue AT 14 WEEKS

\begin{tabular}{|l|c|c|c|}
\hline Treatments & Conventional & SRI & Average \\
\hline Rojolele & $152 \pm 19 \mathrm{~d}$ & $518 \pm 17 \mathrm{abc}$ & 485.00 \\
\hline Cianjur & $759 \pm 26 \mathrm{a}$ & $552 \pm 18 \mathrm{abc}$ & 655.50 \\
\hline Mentikwangi & $620 \pm 24 \mathrm{ab}$ & $307 \pm 14 \mathrm{~cd}$ & 463.50 \\
\hline Ciherang & $175 \pm 12 \mathrm{~d}$ & $474 \pm 12 \mathrm{bc}$ & 324.50 \\
\hline Average & 426.50 & 537.75 & $(+)$ \\
\hline
\end{tabular}

The average number followed by the same letter in a row and column shows not significantly different in DMRT at $\alpha=5 \%$.

$(+)=$ There is a significant interaction between varieties and irrigation.

In the Rojolele and Ciherang varieties, intermittent irrigation produced a longer root length total than conventional irrigation, whereas local rice of Mentikwangi variety, the length of the total roots of conventional irrigation, was significantly longer than intermittent irrigation. In the local rice of Cianjur variety, the length of the total roots of intermittent irrigation was not significantly different from conventional irrigation.

The total root length of Rojolele and Ciherang with intermittent irrigation was longer than conventional irrigation because SRI intermittent irrigation had a dry period that allows the total roots to grow longer in these two rice varieties. Mentikwangi with conventional irrigation had significantly longer total roots than intermittent irrigation, showed that the Mentikwangi variety was also more resistant to inundation.

\section{2) Root Surface Area.}

The total surface area of the roots was measured at $14^{\text {th }}$ weeks using a Leaf Area Meter,a Licor Type, with the Regression Method. The Analysis of Variance and Duncan Multiple Range test in Table 5 showed that there was a significant interaction between varieties and irrigation.

In conventional irrigation, the local rice varieties of Cianjur and Mentikwangi were not significantly different, and these varieties had significantly wider root surface area than the Rojolele and Ciherang variety. In intermittent irrigation, the local rice varieties of Cianjur, Mentiwangi, Rojolele, and Ciherang Varieties were not significantly different (Table 5). In SRI irrigation, the root surface area between varieties was not significantly different because of intermittent irrigation. There was a dry period that allows the root surface to grow wider in all rice varieties.

TABLE $V$

Average Of The Root Surface Area Of Rice Plant Tissue AT 14 WEEKS

\begin{tabular}{|l|c|c|r|}
\hline Treatments & Conventional & SRI & Average \\
\hline Rojolele & $309 \pm 13 \mathrm{de}$ & $998 \pm 35 \mathrm{abc}$ & 653.50 \\
\hline Cianjur & $1452 \pm 44 \mathrm{a}$ & $1062 \pm 46 \mathrm{abc}$ & $1,257.00$ \\
\hline Mentikwangi & $1190 \pm 39 \mathrm{ab}$ & $600 \pm 32 \mathrm{~cd}$ & 895.00 \\
\hline Ciherang & $352 \pm 17 \mathrm{~d}$ & $914 \pm 42 \mathrm{bc}$ & 633.00 \\
\hline Average & 825.75 & 893.50 & $(+)$ \\
\hline
\end{tabular}

The average number followed by the same letter in a row and column shows not significantly different in DMRT at $\alpha=5 \%$.

$(+)=$ There is a significant interaction between varieties and irrigation.

In conventional irrigation, the Cianjur and Mentikwangi varieties had wider root surfaces than other varieties, indicating that this variety was more resistant to inundation than Rojolele and Ciherang. This result showed that the local varieties of Cianjur and Mentikwangi are more resistant to inundation. In the Rojolele Local rice Varieties and Ciherang, intermittent irrigation resulted significantly wider root surface than conventional irrigation, whereas Mentikwangi, the root surface of conventional irrigation, was significantly wider than intermittent irrigation. In the local rice variety Cianjur, intermittent irrigation was not significantly different from conventional irrigation.

In SRI intermittent irrigation, the root surface area between varieties was not significantly different because, with intermittent SRI irrigation, there was a dry period that allows the root surface to grow wider in all rice varieties. In conventional irrigation, the Cianjur and Mentikwangi varieties had wider root surfaces than other varieties, indicating that both of these varieties were more resistant to inundation than the Rojolele and Ciherang varieties.

\section{Chlorophyll content}

\section{1) Chlorophyll a}

Analysis of chlorophyll content consists of chlorophyll a, chlorophyll b, and total chlorophyll. The results of the analysis were presented in Table 6 .

TABLE VI

Average Of The Chlorophyll A, Chlorophyll B, AND Chlorophyll Total Content Of Rice Plant Tissue At 10 WeEks

\begin{tabular}{|l|l|l|l|}
\hline Treatments & $\begin{array}{l}\text { chlorophyll a } \\
(\mathrm{mg} / \mathrm{g})\end{array}$ & $\begin{array}{l}\text { chlorophyll b } \\
(\mathrm{mg} / \mathrm{g})\end{array}$ & $\begin{array}{l}\text { chlorophyll } \\
\text { total }(\mathrm{mg} / \mathrm{g})\end{array}$ \\
\hline Rojolele & $28.48 \pm 2.90 \mathrm{a}$ & $13.66 \pm 4.06 \mathrm{~b}$ & $42.16 \pm 6.93 \mathrm{a}$ \\
Cianjur & $26,50 \pm 8.38 \mathrm{a}$ & $34.94 \pm 7.25 \mathrm{a}$ & $61.44 \pm 4.61 \mathrm{a}$ \\
Mentikwangi & $29.30 \pm 3.80 \mathrm{a}$ & $33.75 \pm 3.40 \mathrm{a}$ & $63.06 \pm 5.40 \mathrm{a}$ \\
Ciherang & $27.08 \pm 7.28 \mathrm{a}$ & $25.81 \pm 5.02 \mathrm{ab}$ & $52.90 \pm 2.21 \mathrm{a}$ \\
\hline Conventional & $28.72 \pm 4.48 \mathrm{p}$ & $30.81 \pm 8.14 \mathrm{p}$ & $61.72 \pm 7.79 \mathrm{p}$ \\
SRI & $26.96 \pm 6.70 \mathrm{p}$ & $28.97 \pm 2.43 \mathrm{p}$ & $58.98 \pm 7.29 \mathrm{p}$ \\
\hline Interaction & $(-)$ & $(-)$ & $(-)$ \\
\hline
\end{tabular}

The average number followed by the same letter in a column shows not significantly different in DMRT at $\alpha=5 \%$.

$(-)=$ There is no significant interaction between varieties and irrigation. 
The treatment of varieties did not significantly affect the chlorophyll a and chlorophyll total content of rice in the 10th week. The varieties did not influence the chlorophyll a and chlorophyll total content of rice plants. Water treatment also showed no significant effect on the chlorophyll a and chlorophyll total content of rice plants, meaning that intermittent and conventional irrigation had not significantly affected on the chlorophyll a and chlorophyll total content (Table 6). Local rice varieties Rojolele, Cianjur, and Mentikwangi, had not significantly different responses in the formation of chlorophyll a and total chlorophyll compared to superior Ciherang rice. The content of chlorophyll a and total chlorophyll was not affected by the type of irrigation, indicating that the dry period in intermittent irrigation of SRI did not affect the formation of chlorophyll a and total chlorophyll. Variety treatment significantly affected the chlorophyll $b$ of the $10^{\text {th }}$-week rice plant. Rice varieties influence the chlorophyll $b$ content of rice plants. Chlorophyll b content of Cianjur and Mentikwangi were higher than Rojolele. Irrigation treatment showed no significant effect on the chlorophyll b content of rice plants. Intermittent and conventional irrigation did not significantly affect the chlorophyll $\mathrm{b}$ content of rice plants.

Cianjur and Mentikwangi local rice varieties had a higher response in the formation of chlorophyll $b$ than Rojolele rice. The chlorophyll $b$ content was not affected by the type of irrigation, indicating that the dry period in intermittent watering SRI did not affect the formation of chlorophyll $b$.

\section{Rice Yield}

Several generative plant growth factors influence grain yield per hectare. The higher the grain yield was, the higher the productivity of rice plants will be. Based on the results, the analysis of variance shows that there was no significant interaction between irrigation and varieties of grain yield per hectare. The variety treatment showed a significant effect, whereas the irrigation treatment had not significantly effect on grain yield. The average grain yield was presented in Table 7. Grain yields of the local rice varieties of Cianjur, Mentikwangi, and Rojolele have not significantly different. The yield of Cianjur Variety is significantly higher than the Ciherang variety. Intermittent irrigation is not significantly different from conventional irrigation in yielding per hectare of dry grain.

TABLE VII

AVERAGE OF GRAIN YIELD OF RICE

\begin{tabular}{|l|c|}
\hline Treatments & Grain yield (t/ha) \\
\hline Rojolele & $4.87 \pm 0.32 \mathrm{ab}$ \\
Cianjur & $5.54 \pm 0.58 \mathrm{a}$ \\
Mentikwangi & $5.04 \pm 0.25 \mathrm{ab}$ \\
Ciherang & $4.71 \pm 0.44 \mathrm{~b}$ \\
\hline Conventional & $4.99 \pm 0.29 \mathrm{p}$ \\
SRI & $5.09 \pm 0.40 \mathrm{p}$ \\
\hline Interaction & $(-)$ \\
\hline
\end{tabular}

The average number followed by the same letter in a column shows not significantly different in DMRT at $\alpha=5 \%$.

$(-)=$ There is no significant interaction between varieties and irrigation.

The yield per hectare of three local rice varieties was not significantly different, indicating that the production capacity of these three varieties is following the potential yield of local rice. The yield per hectare of Cianjur rice is
$5.54 \mathrm{t} / \mathrm{ha}$, significantly higher than the Ciherang variety of $4.71 \mathrm{t} / \mathrm{ha}$, although it is still lower than the average Cianjur rice production of $5.7 \mathrm{t} / \mathrm{ha}$ [22]

\section{E. Correlation of secondary macronutrient absorption, root development, chlorophyll content, and rice yield}

Correlations between secondary macronutrient absorption, root development, chlorophyll content, and rice yield in various varieties and irrigation are in Table 8. Calcium, Magnesium, and Sulfur absorption were significantly correlated negatively with yields per hectare of rice. The higher absorption of Calcium, Magnesium and Sulfur consequently the yield per hectare will be lower. Calcium absorption had a significant and positive correlation with Magnesium absorption. Calcium and Magnesium absorption also had a significant and positive correlation. The higher absorption of Calcium will increase the Magnesium absorption, and the higher absorption of Magnesium will increase the absorption of Calcium. This result was contrary to the statement that increasing levels of nutrient $\mathrm{Ca}^{2+}$ in the soil will cause competition with other cations such as $\mathrm{Mg}^{2+}$ absorbed by plants so that high $\mathrm{Ca}$ absorption can reduce $\mathrm{Mg}^{2+}$ absorption [23]. Also, high Ca concentrations would inhibit $\mathrm{Mg}$ absorption, leading to $\mathrm{Mg}$ deficiency [24].

The content of chlorophyll a and chlorophyll $b$ had a significant and positive correlation with the total chlorophyll content. The higher the content of Chlorophyll a and chlorophyll $\mathrm{b}$ will increase the total chlorophyll content. Total root length, root surface area, and chlorophyll a content had a significant and positive correlation with chlorophyll $\mathrm{b}$ content. The higher the total root length, the root surface area and chlorophyll a content will increase the chlorophyll b content.

TABLE VIII

CORRElation BetweEn SECONDARY MACRO NuTRIENT ABSORPTION, ROOT DEVELOPMENT AND RICE YIELD

\begin{tabular}{|c|c|c|c|c|c|c|c|c|c|}
\hline & $\mathrm{Ca}$ & Mg & $\mathbf{S}$ & RLT & RAS & $\begin{array}{c}\text { CHL } \\
\text { A }\end{array}$ & $\begin{array}{c}\text { CHL } \\
\text { B }\end{array}$ & $\underset{\mathbf{T}}{\mathbf{C H L}}$ & RY \\
\hline $\mathrm{Ca}$ & 1.0 & $\begin{array}{l}0.89 \# \\
<.01\end{array}$ & $\begin{array}{l}0.07 \\
0.74\end{array}$ & $\begin{array}{l}0.07 \\
0.74\end{array}$ & $\begin{array}{l}0.07 \\
0.74\end{array}$ & $\begin{array}{l}0.12 \\
0.58\end{array}$ & $\begin{array}{l}-0.10 \\
0.63\end{array}$ & $\begin{array}{l}-0.04 \\
0.85\end{array}$ & \begin{tabular}{|l}
$-0.49 *$ \\
0.02
\end{tabular} \\
\hline $\mathrm{Mg}$ & & 1.0 & $\begin{array}{l}0.23 \\
0.28\end{array}$ & $\begin{array}{l}-0.13 \\
0.56\end{array}$ & $\begin{array}{l}-0.13 \\
0.56\end{array}$ & $\begin{array}{l}0.08 \\
0.72\end{array}$ & $\begin{array}{l}-0.33 \\
0.13\end{array}$ & $\begin{array}{l}-0.23 \\
0.29\end{array}$ & $\begin{array}{l}-0.53 \# \\
<0.01\end{array}$ \\
\hline $\mathrm{S}$ & & & 1.0 & $\begin{array}{l}-0.33 \\
0.12\end{array}$ & $\begin{array}{l}-0.33 \\
0.12\end{array}$ & $\begin{array}{l}-0.21 \\
0.32\end{array}$ & $\begin{array}{l}-0.33 \\
0.12\end{array}$ & $\begin{array}{l}-0.32 \\
0.12\end{array}$ & $\begin{array}{l}-0.38 \\
0.06\end{array}$ \\
\hline RLT & & & & 1.0 & $\begin{array}{l}1.00 \# \\
<.01\end{array}$ & $\begin{array}{l}0.06 \\
0.79\end{array}$ & $\begin{array}{l}0.42 * \\
0.04\end{array}$ & $\begin{array}{l}0.34 \\
0.10\end{array}$ & $\begin{array}{l}0.11 \\
0.61\end{array}$ \\
\hline RAS & & & & & 1.0 & $\begin{array}{l}0.06 \\
0.79\end{array}$ & $\begin{array}{l}0.42 * \\
0.04\end{array}$ & $\begin{array}{l}0.34 \\
0.10\end{array}$ & $\begin{array}{l}0.11 \\
0.61\end{array}$ \\
\hline CHLA & & & & & & 1.0 & $\begin{array}{l}0.57 \# \\
<0.01\end{array}$ & $\begin{array}{l}0.77 \# \\
<.01\end{array}$ & $\begin{array}{l}-0.16 \\
0.44\end{array}$ \\
\hline CHLB & & & & & & & 1.0 & $\begin{array}{l}0.96 \# \\
<.01\end{array}$ & $\begin{array}{l}0.23 \\
0.27\end{array}$ \\
\hline CHLT & & & & & & & & 1.0 & $\begin{array}{l}0.13 \\
0.56\end{array}$ \\
\hline RY & & & & & & & & & 1.0 \\
\hline $\begin{array}{l}\text { \#: corre } \\
* \text { : corre } \\
\text { CHLA } \\
\text { CHLT: }\end{array}$ & $\begin{array}{l}\text { lation } \\
\text { lation } \\
\text { Chlo } \\
\text { Chlo }\end{array}$ & $\begin{array}{l}\text { A signifi } \\
\text { n signifi } \\
\text { rophyll } \\
\text { rophyll }\end{array}$ & otal & $\alpha=1$ & & \multicolumn{4}{|c|}{$\begin{array}{l}\text { RLT: root length total } \\
\text { RAS: root area surface } \\
\text { CHLB: Chlorophyll b } \\
\text { RY : Rice Yield }\end{array}$} \\
\hline
\end{tabular}


F. Regression of Calcium, Magnesium, and Sulfur absorption with rice yields.

The relationship between $\mathrm{Ca}$ absorption and yield per hectare followed the non-linear power pattern significantly with the equation $\mathrm{Y}=4.611 \mathrm{X}^{0.085}$, with a probability error of 0.004 with $r$ value 0.561 . (Figure 4).

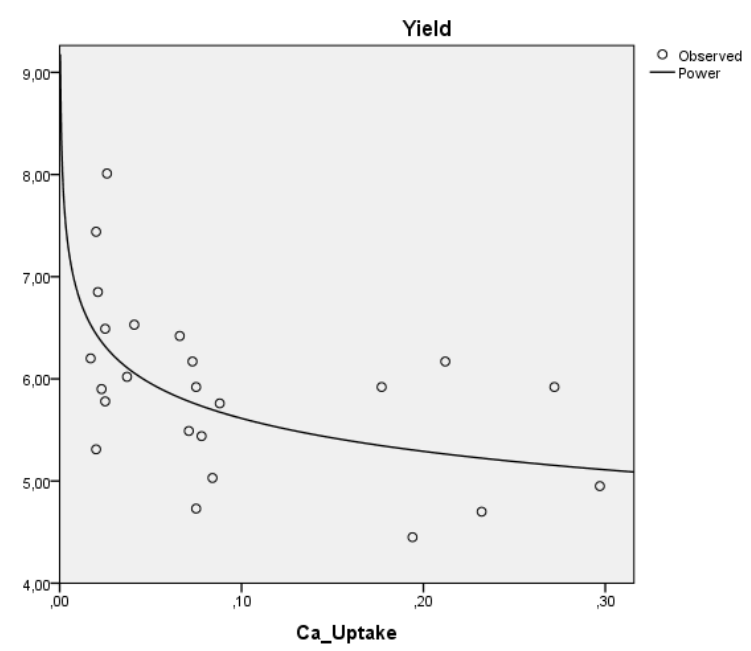

Fig. 4 Regression of relationship between $\mathrm{Ca}$ absorption with yield per hectare of rice

The relationship of $\mathrm{Mg}$ absorption with yield per hectare followed the non-linear logarithmic pattern significantly with the equation $\mathrm{Y}=3.925-0.516 \mathrm{LnX}$, with a probability error of 0.005 and an r-value of 0.561 (Figure 5).

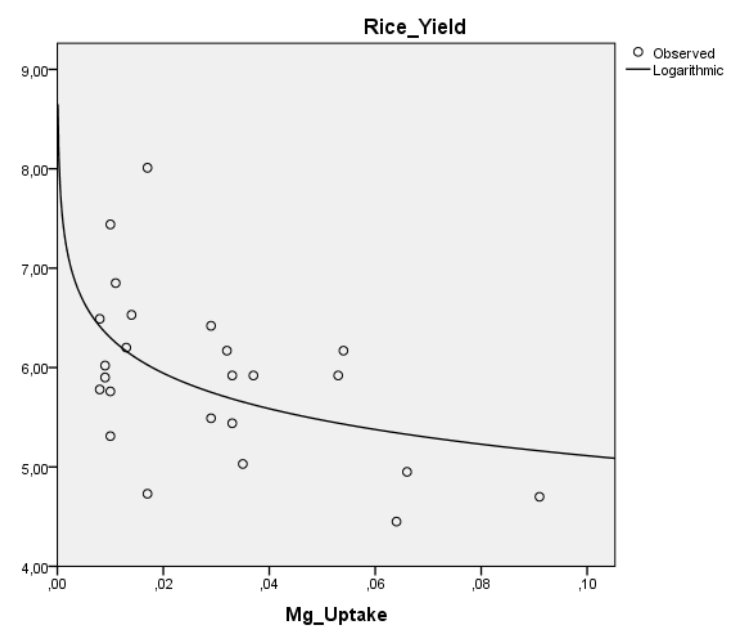

Fig. 5 Regression of relationship between $\mathrm{Mg}$ absorption with yield per hectare of rice

Increasing the total absorption of $\mathrm{Ca}$ will influence the yield decrease with the regression equation above because the nutrient content of $\mathrm{Ca}$ in the study before and after the research was very high, that is $10.99 \mathrm{me} \%(>5)$ and 11.35 me $\%(>5)$ respectively [25].

Increasing the total absorption of $\mathrm{Mg}$ will influence the yield decrease with the regression equation above because the nutrient content of $\mathrm{Mg}$ in the study before and after the research was high, that is $0.68 \mathrm{me} \%(>0.5)$ and $0.79 \mathrm{me} \%$ $(>0.5)$ respectively [25].

\section{IV.CONCLUSION}

The results showed that variety and irrigation have interaction to the secondary macronutrient and root development. The local variety of Rojolele with SRI irrigation had higher secondary macronutrient absorption than the local varieties of Cianjur and Mentikwangi. Calcium nutrient absorption of Rojolele and Ciherang with SRI irrigation was higher than other varieties, whereas Magnesium nutrient absorption of Rojolele with SRI irrigation was higher than Ciherang, Cianjur and Mentikwangi local varieties. Rojolele with SRI irrigation had higher Sulfur nutrient absorption than Cianjur and Mentikwangi. In Rojolele and Ciherang, intermittent irrigation SRI produces roots longer and more wide root surface area than conventional irrigation, but on Mentikwangi, conventional irrigation produces longer roots at harvest, and more wide root surface area than intermittent SRI irrigation. The chlorophyll $b$ content of the Cianjur and Mentikwangi were higher than Rojolele. The yield of Cianjur had higher than Ciherang.

\section{ACKNOWLEDGMENT}

This research was supported by the Indonesian Ministry of Research and Technology and Higher Education under the program of the Doctoral Dissertation Research Fund for year 2019 .

\section{REFERENCES}

[1] Isnawan, B.H., Susila, dan Mulyono. 2018. A Study of Physiology of Rice Varieties with Intermittent Irrigation and Conventional Method on System of Rice Intensification. 4th International Conference on Food and Agriculture Resources (FANRes 2018). Advances in Engineering Research, 172:155-160.

[2] Badan Pusat Statistik. 2018. Produksi Padi, Jagung, dan Kedelai 2015. Dalam Berita Resmi Statistik 7(62): 1-10.

[3] Norrman Uphoff. 2008. The System Of Rice Intensification (SRI) As A System Of Agricultural Innovation. Jurnal Tanah dan Lingkungan 10 (1): 27-40.

[4] Rochayati. 2011. Analisis Komparatif Sitem Pertanian Konvensional, PTT dan SRI di Lahan Sawah Irigasi Jawa Barat terhadap Keseimbangan Hara, Dinamika Biologi,Efisiensi Pupuk (> 30\%) dan Nilai Ekonomi Usahatani . Laporan Akhir Program Insentif Riset Terapan. Balai Penelitian Tanah Balai Besar Litbang Sumberdaya Lahan PertanianBadan Penelitian Dan Pengembangan Pertanian

[5] Febri Doni, M. S.Mispan \& N. S. M. Suhaimi, N. Ishak and N. Uphoff. 2019. Roles of microbes in supporting sustainable rice production using the system of rice intensification. Appl Microbiol Biotechnol 103:5131-5142

[6] Arum Asriyanti Suhastyo, Iswandi Anas, Dwi Andreas Santosa, dan Yulin Lestari. 2013. Studi Mikrobiologi Dan Sifat Kimia MikroorganismeLokal (Mol) Yang Digunakan Pada BudidayaPadi Metode SRI (System Of Rice Intensification). Sainteks 10(2): 29 - 38

[7] Suhastyo, A.A, I. Anas. D.A. Santoso, dan dan Y. Lestari 2013.Studi Mikrobiologi Dan Sifat Kimia Mikroorganisme Lokal (Mol) Yang Digunakan Pada Budidaya Padi Metode Sri (System Of Rice Intensification). Sainteks 10(2): 29 -39.

[8] Hidayati N. 2015. Fisiologi, Anatomi dan Sistem Perakaran Pada Budidaya Padi Dengan Metode System Of Rice Intensification (SRI) Synopsis of water management experiments in Indonesia. In Bouman, B.A.M., H. Hengsdijk, B. Hardy, P.S. Bindraban, T.P. Tuong, dan J.K. Ladha (Eds.). Waterwise Rice Production. Plant Research International. IRRI

[9] Astuti, D.N. 2009. Pengaruh Sistem Pengairan terhadap Pertumbuhan dan Produktivitas Beberapa Varietas Padi Sawah (Oryza sativa L.). Institut Pertanian Bogor.

[10] Sauki, A., A. Nugroho, dan R. Soelistyono. 2014. Pengaruh Jarak Tanam Dan Waktu Penggenangan Pada Metode SRI (System of Rice 
Intensification) Terhadap Pertumbuhan Dan Hasil Tanaman Padi (Oryza Sativa L.). Jurnal Produksi Tanaman, 2(2): 121-127

[11] Regazzoni, O., Yogi Sugito, dan Agus Suryanto. 2013. Sistem Irigasi Berselang (Intermittent Irrigation) Pada Budidaya Padi (Oryza Sativa L.) Varietas Inpari-13 Dalam Pola Sri (System of Rice Intensification). Jurnal Produksi Tanaman 1(2): 42 - 51.

[12] Mungara E., D. Indradewa, dan R. Rogomulto. 2013. Analisis Pertumbuhan Dan Hasil Padi Sawah (Oryza Sativa L.) Pada Sistem Pertanian Konvensional, Transisi Organik, Dan Organik.Vegetalika 2 (3): 1-12.

[13] Yudono, P., D. Indradewa, Sarjiman, dan Syamsuddin. 2010.Kajian Karakter Fisiologis Dan Agronomis Padi Efisien Air (> 500/0), Produktivitas Tinggi ( $>8 \mathrm{~T} / \mathrm{Ha}$ ) Dengan Sistem Genangan Dalam Parit Di Tanah Regosol Berpengairan Teknis. Ringkasan Eksekutif Hasi-hasil Penelitian tahun 2010. Kerjasama Kemitraan Penelitian Pertanian dengan Perguruan Tinggi (KKP3T).

[14] Lestari, A. 2012. Uji daya hasil beberpa varietas padi dengan metode SRI di Solok. Fakultas Pertanian Universitas Andalas Padang.

[15] Makarim, A.K., V. Balasubramanian, Z. Zaini, I. Syamsiah, I.G.P.A Diratmadja, Handoko, Arafah, IP. Wardana, dan A. Gani. 2002. System of Rice Intensification (SRI): Evaluation of seedling age and selectedcomponents in Indonesia. Dalam Bouman, B.A.M., H Hengsdijk, B. Hardy, P.S. Bindraban, T.P. Tuong, dan J.K. Ladha (Eds.). Waterwise Rice Procuction. Plant Research International. IRRI.
[16] Syekhfani. 1997. Hara, Air Tanah, dan Tanaman. Jurusan Ilmu Tanah,Fakultas Pertanian, Universitas Brawijaya. Malang.

[17] Lingga P dan Marsono. 2008. Petunjuk Penggunaan Pupuk. Penebar Swadaya. Bandung.

[18] Winarso, S. 2005. Kesuburan Tanah, Dasar Kesehatan dan Kualitas Tanah. Gava Media. Yogyakarta.

[19] Thakur, A.K., S. Rath, S. Roychowdhury and N. Uphoff. 2010 Comparative Performance of Rice with System of Rice Intensification (SRI) and Conventional Management using Different Plant Spacings. J. Agronomy \& Crop Science 196: 146-159.

[20] Martini, J.A., dan R.G. Mutters. 1985. Effect of lime rates on nutrient availability, mobility, Magnesium, Potassium,Iron, Copper, and Zinc. Soil Sci., 139 (4): 333-343.

[21] Mengel and Kirby 1987 Mengel, K. dan E.A. Kirby. 1987. Principles of plant nutrition. 4th Edition. International Potash Institute, Bern, Switzerland.

[22] Keputusan Menteri Pertanian. 2017. Data 5 tahunan Produksi Padi Menurut Provinsi. Jakarta. http://www.pertanian.go.id.

[23] Havlin J.L., Beaton J.D., Tisdale SL, dan Nelson WL. 1999. Soil Fertility and Ferlitizer; An Introduction to Nutrient Management. Sixth edition. New Jersey: Prentice Hall. Upper Saddle River.

[24] Jones J.B. 1998. Plant Nutrition Manual. CRC Press. New York

[25] Landon. 1984. Landon, J.R. (ed). 1984. Booker Tropical Soil Manual. Booker Agric. Intern. Ltd. 